\title{
OCENA WARUNKÓW PRZEWOZU I DOBROSTANU TUCZNIKÓW W TRANSPORCIE LOKALNYM
}

\author{
Krzysztof Tereszkiewicz ${ }^{1}$, Piotr Molenda ${ }^{2}$, Dariusz Kusz ${ }^{1}$ \\ ${ }^{1}$ Zakład Informatyki w Zarządzaniu Politechniki Rzeszowskiej \\ Kierownik Zakładu: dr hab. inż. Krzysztof Tereszkiewicz, prof. PRz \\ ${ }^{2}$ Zakład Polityki Regionalnej i Gospodarki Żywnościowej Uniwersytetu Rzeszowskiego \\ Kierownik Zakładu: dr hab. Andrzej Zapałowski
}

\begin{abstract}
Słowa kluczowe: transport tuczników, warunki przewozu, dobrostan, odległość transportu, skala produkcji, straty ekonomiczne

Key words: fatteners transportation, transport conditions, welfare, distance transport, production scale, economical losses, scales of production
\end{abstract}

\begin{abstract}
S y n o p s i s. Celem opracowania była ocena warunków transportu i dobrostanu tuczników oraz oszacowanie ekonomicznych strat transportowych w zależności od odległości transportu i wielkości rocznej skali produkcji tuczników. Badania przeprowadzono w latach 2014-2015 metodą ankiety bezpośredniej. Materiał badawczy stanowiły dane opisujące 120 operacji transportowych, w których trakcie do uboju przewieziono łącznie 4300 tuczników. $Z$ badań własnych wynika, że zwierzęta były przewożone zarówno pojazdami specjalistycznymi, jak i adaptowanymi środkami transportowymi, głównie agregatami rolniczymi. Pojazdy specjalistyczne częściej wykorzystywano w transporcie na większe odległości i z gospodarstw o większej rocznej skali produkcji tuczników. Przeprowadzone badania wykazały liczne przypadki przekroczenia dopuszczalnych norm obsady tuczników w czasie transportu, głównie w transportach realizowanych od największych producentów. Najwyższe straty ekonomiczne wynikające z obniżenia dobrostanu tuczników w przeliczeniu na jedno transportowane zwierzę odnotowano w przewozach na najdłuższym dystansie oraz z gospodarstw o największej skali produkcji.
\end{abstract}

\section{WSTĘP}

Całokształt czynności i operacji logistycznych związanych z przekazaniem tuczników z sektora produkcji do sektora uboju jest określany jako obrót przedubojowy. Integralną część tych operacji stanowi transport. Organizacja przepływu tuczników ze sfery produkcji do sfery przetwórstwa z wykorzystaniem transportu powinna zagwarantować ciągłość i rytmiczność procesu zaopatrzenia przy równoczesnym zachowaniu współczesnych zasad wysokiego dobrostanu zwierząt. W przewozach tuczników dominuje transport samochodowy [Cierach, Idaszewska 2014]. Decyduje głównie o tym jego elastyczność, przejawiająca się możliwością bezpośredniego dostarczenia żywca z gospodarstw do zakładów ubojowych, co ogranicza liczbę czynności przeładunkowych i znacząco skraca czas transportu. Pomimo że transport zwierząt rzeźnych w krajach Unii Europejskiej (UE) charakteryzuje się coraz lepszą organizacją i wyposażeniem technicznym [Matysek i in. 
2013] oraz znajduje się pod szczególnym nadzorem społecznym i prawnym [Malak-Rawlikowska i in. 2010], nadal wiele aspektów i procedur wymaga doskonalenia. Problemy w transporcie zwierząt rzeźnych mają zasięg ogólnobranżowy i dotyczą całego sektora mięsnego, jak również występują na poziomie lokalnym.

Istotnym zagadnieniem utrudniającym właściwe funkcjonowanie transportu świń rzeźnych w Polsce jest znaczne rozdrobnienie sektora produkcji. W UE produkcja żywca wieprzowego charakteryzuje się bardzo wysokim wskaźnikiem koncentracji [Ziętara 2014]. Decydujący udział w zaopatrzeniu przetwórstwa mięsnego w surowiec mają przedsiębiorstwa o wysokiej skali produkcji. Ten model jest realizowany w krajach, które są głównymi producentami wieprzowiny w UE, zwłaszcza w Danii, Belgii, Holandii i Niemczech. W krajach będących czołowymi producentami w UE przeciętna wielkość stada zawiera się w przedziale 700-1200 sztuk. W ostatnich latach również w Polsce obserwuje się wzrost wskaźnika koncentracji produkcji żywca wieprzowego, jednak dystans do głównych producentów świń rzeźnych w Europie jest znaczący. W Polsce przeciętna wielkość stada świń wynosi około 40 sztuk. W produkcji żywca wieprzowego dominują gospodarstwa, w których roczna skala nie przekracza 50 tuczników, a udział gospodarstw produkujących od 50 do 200 wynosi jedynie około 12\% [Ziętara 2014]. Rozdrobnienie, niski poziom specjalizacji i efektywności są uznawane za zasadnicze przyczyny spadku znaczenia Polski w UE jako producenta wieprzowiny [Kusz 2005]. Na tle złej kondycji sektora trzodowego w Polsce warto również zwrócić uwagę na wyraźne różnice w systemach produkcji świń, występujące między poszczególnymi regionami kraju [Utnik-Banaś 2015]. Regionem o wyjątkowo niskiej koncentracji produkcji żywca wieprzowego jest Podkarpacie. Równocześnie na terenie województwa podkarpackiego istnieje dość dobrze rozwinięta baza przetwórstwa wieprzowiny, która w sytuacji braku surowca rzeźnego w bezpośrednim otoczeniu zmuszona jest do jego poszukiwań w innych rejonach kraju bądź do importu. Taka sytuacja skutkuje koniecznością transportu tuczników niekiedy na znaczne odległości.

Istotnym elementem problemów organizacyjnych w transporcie trzody chlewnej jest nieprzestrzeganie zasady, zgodnie z którą tuczniki powinny być kierowane do uboju w zakładach rzeźnych zlokalizowanych najbliżej miejsca ich produkcji. Główną przyczyną uboju tuczników poza miejscem ich produkcji są znaczne różnice w cenach żywca wieprzowego obserwowane między poszczególnymi krajami i regionami UE. Nowym zagrożeniem dla sektora trzody chlewnej w Polsce, który może wywołać poważne implikacje w transporcie, jest rozprzestrzeniająca się na obszarze Polski epidemia afrykańskiego pomoru świn - ASF (łac. Pestis africana suum). Istotnym wektorem tej niezwykle niebezpiecznej choroby wirusowej świń jest transport [Zagrożenia dla ... 2015, s. 9].

Przewozy tuczników z miejsca produkcji do uboju są jedną z bardziej złożonych i trudnych do przeprowadzenia operacji logistycznych realizowanych w sektorze agrobiznesu. Transport zwierząt rzeźnych w powszechnej świadomości, potwierdzonej licznymi wynikami badań [Nanni-Costa i in. 1999, Ritter i in. 2006, Tereszkiewicz i in. 2003, Tereszkiewicz i in. 2004], przyczynia się do obniżenia dobrostanu zwierząt. Ważnymi czynnikami mogącymi spowodować obniżenie dobrostanu tuczników w obrocie przedubojowym są: metoda załadunku i wyładunku, warunki transportu, wśród których szczególne znaczenia ma: odległość transportu, powierzchnia podłogi, obecność ściółki, elementy wyposażenia technicznego pojazdów. Właściwe przygotowanie i przeprowadzenie transportu zwierząt zależy również od potencjału technicznego gospodarstw produkujących żywiec oraz stopnia ich specjalizacji oraz związanej z nią skalą produkcji [Kusz 2005, Pisula, Florowski 2008, Tereszkiewicz i in. 2011]. 
Dotychczasowe wyniki wieloletnich badań własnych w obszarze transportu tuczników ugruntowały przekonanie o wielowymiarowości i złożoności badanej problematyki. Świnie należą do zwierząt o bardzo wysokiej wrażliwości na niekorzystne bodźce środowiskowe. Wysoka stresopodatność świń wynika ze specyficznych cech gatunkowych, wśród których podkreśla się właściwości układu naczyniowo-sercowego oraz termoregulacyjnego, jak również cechy anatomiczne [Kołacz 2010]. Wymienione cechy w sposób istotny utrudniają prawidłowe i skuteczne uruchomienie mechanizmu adaptacyjnego, zwłaszcza podczas transportu. Można przyjąć, że każda operacja przewozowa niesie ryzyko wystąpienia u zwierząt tego gatunku stresu transportowego, który ma charakter polietiologiczny. Głównymi czynnikami stresogennymi, z którymi zwierzęta mogą się zetknąć w czasie transportu, są: ruch pojazdów, hałas, ograniczenie przestrzeni życiowej, kontakt z obcymi osobami, intensywne przepędzanie i bicie, obce środowisko socjalne, zmiana warunków świetlnych i termiczno-wilgotnościowych.

Przy planowaniu zadań przewozowych związanych z transportem zwierząt rzeźnych istotne znaczenie mają czynniki ekonomiczne związane z kosztami transportu. Wysokość kosztów przewozu zwierząt zależy od czasu trwania i odległości do przebycia, liczby przewożonych zwierząt, stopnia wykorzystania ładowności środka transportowego, cen paliwa i materiałów eksploatacyjnych, kosztów pracy kierowców i konwojentów. Według Stanisława Kokoszki zmniejszenie kosztów transportu zwierząt można osiągnąć przez właściwy dobór środków transportu, sprawną organizację procesów transportowych i minimalizację kosztów eksploatacji sprzętu [Kokoszka 2009]. Uwzględniając te zalecenia, trzeba podkreślić, że najbardziej efektywne w przewozie zwierząt rzeźnych są specjalistyczne środki transportu o dużej ładowności, pod warunkiem odpowiedniej wielkości jednorazowo przewożonego ładunku. Istotnym czynnikiem determinującym efektywność transportu zwierząt rzeźnych są również koszty wynikające z obniżenia wartości technologicznej przewożonych zwierząt, na które składają się straty finansowe wynikające z nieprzestrzegania zasad dobrostanu. Straty te są związane z takimi elementami, jak: upadki zwierząt, obniżenie wskaźnika wydajności rzeźnej, konfiskaty części surowca będące skutkiem obrażeń ciała. Istotną pozycję stanowią również straty wynikające z wystąpienia wad jakościowych mięsa. Straty związane z wymienionymi czynnikami mogą stanowić nawet 30\% wartości tucznika [Ritter i in. 2009]. Rebecca Kephart z zespołem wykazała, że straty powstałe na skutek upadków tuczników w czasie transportu w USA w roku 2011 wynosiły ponad 21 mln dolarów [Kephart i in. 2011]. Przyjmując uśredniony wskaźnik upadków tuczników w krajach UE na poziomie 0,07\% przy rocznej produkcji wynoszącej 250 mln tuczników i średniej wartości jednego tucznika 150 euro, straty sektora mięsnego można oszacować na około $26 \mathrm{mln}$ euro. Analogicznie w Polsce można je oszacować na około 1,8 mln euro.

Celem opracowania była ocena warunków transportu i dobrostanu tuczników oraz oszacowanie ekonomicznych strat w zależności od odległości transportu i wielkości rocznej skali produkcji tuczników na poziomie lokalnym.

\section{METODYKA}

Badania przeprowadzono w latach 2014-2015 metodą ankietową bezpośrednią. Materiał badawczy stanowiły dane opisujące 120 operacji transportowych wybranych losowo, w trakcie których do uboju przewieziono łącznie 4300 tuczników. Tuczniki dostarczano do trzech zakładów ubojowych zlokalizowanych na terenie województwa podkarpackiego. Odległość transportu wynosiła od $2 \mathrm{~km}$ do $560 \mathrm{~km}$. Ze względu na odległość oceniane 
transporty podzielono na trzy kategorie: do $20 \mathrm{~km}, 20-50 \mathrm{~km}$, powyżej $50 \mathrm{~km}$. Zwierzęta były transportowane bezpośrednio z miejsca produkcji do ubojni. Wyniki uzyskanych badań analizowano również z uwzględnieniem rocznej skali produkcji tuczników w gospodarstwach, z których pochodziły transportowane zwierzęta. Według tego kryterium, wyodrębniono cztery kategorie gospodarstw: do 20, 20-50, 51-100 i powyżej 100 tuczników. W trakcie badań określono warunki techniczne transportu, obejmujące ocenę metody załadunku (winda, rampa), rodzaje pojazdów wykorzystywanych do przewozu tuczników, typ podłogi (metalowa, drewniana), systemy ściółkowe (z uwzględnieniem rodzaju ściółki) i bezściółkowe, obliczono powierzchnię podłogi przypadającej na jedno zwierzę. Po zakończeniu transportu i wyładunku określono udział zwierząt z widocznymi obrażeniami ciała oraz udział zwierząt wykazujących objawy zmęczenia potransportowego. Do oszacowania strat ekonomicznych związanych z występowaniem negatywnych skutków transportu w postaci zmęczenia zwierząt i obrażeń ciała zastosowano wskaźniki zaproponowane przez Matthew Rittera z zespołem [Ritter i in. 2006]. Dla zwierząt z objawami zmęczenia przyjęto wskaźnik strat wynoszący $0,44 \%$, natomiast dla zwierząt z obrażeniami ciała wskaźnik strat wynoszący $0,15 \%$. Do obliczenia wartości strat przyjęto średnią cenę żywca wieprzowego za $1 \mathrm{~kg}$ wagi żywej w roku 2015 dla województwa podkarpackiego wynoszącą 4,23 zł/kg [https://bdl.stat.gov.pl/BDL/start]. Wyniki badań poddano ocenie statystycznej, podając wartości procentowe, które nie zawsze sumują się do 100\%, ponieważ część ankiet miało braki niektórych kategorii odpowiedzi.

\section{WYNIKI I OMÓWIENIE}

Załadunek jest uznawany za jeden z ważniejszych punktów krytycznych w transporcie zwierząt. Czynności załadunkowe powinny być przeprowadzone w sposób profesjonalny z wykorzystaniem właściwych urządzeń. Aktualnie do załadunku zwierząt wykorzystuje się pochylnie, rampy załadowcze lub windy. Z wcześniejszych badań własnych [Tereszkiewicz i in. 2017] wynika, że w Polsce najczęściej do załadunku wykorzystuje się pochylnie. Jednak ze względu na dobrostan zwierząt korzystniejszą metodą załadunku tuczników są windy [Nanni-Costa i in. 1999]. Urządzenia te pozwalają wyeliminować konieczność forsowania przez zwierzęta pochyłości. Świnie mają szczególnie trudności w ich pokonywaniu, niechętnie wchodzą na strome podejścia, ślizgają się i zawracają. Stwierdzono, że wykorzystanie do załadunku wind znacząco ogranicza niekorzystne reakcje zwierząt i w sposób istotny przyczynia się do obniżenia wskaźnika obrażeń, zmęczenia oraz upadków zwierząt [Ritter i in. 2009].

Stosowane metody załadunku z uwzględnieniem skali produkcji i odległości transportu tuczników przedstawiono w tabeli 1 . Za pomocą pochylni odbywał się załadunek wszystkich tuczników dostarczanych z gospodarstw produkujących rocznie od 10 do $20 \mathrm{i}$ od 21 do 50 zwierząt oraz $83,2 \%$ tuczników pochodzących z gospodarstw o rocznej skali produkcji od 50 do 100 tuczników. Część tuczników pochodząca z gospodarstw o większej rocznej skali produkcji była ładowana za pomocą wind. Szczególnie znaczący wzrost udziału tej metody załadunku odnotowano w gospodarstwach o rocznej skali produkcji ponad 100 tuczników. Zdecydowanie większy udział wind w załadunku świń pochodzących z największych gospodarstw miał związek z wykorzystywanymi przez te podmioty środkami transportu, które były wyposażone w windy lub platformy załadowcze.

Analizując metody załadunku z uwzględnieniem odległości transportu tuczników stwierdzono, że za pomocą pochylni w środkach transportu umieszczano 97,8\% zwierząt 
Tabela 1. Charakterystyka metod załadunku, rodzaju pojazdów stosowanych w transporcie tuczników, typów podłóg, systemów przewozów z uwzględnieniem rodzaju ściółki oraz obsada zwierząt i udział zwierząt z obrażeniami ciała i wykazujących objawy zmęczenia potransportowego w zależności od skali produkcji i odległości transportu tuczników (\%)

\begin{tabular}{|c|c|c|c|c|c|c|c|}
\hline \multirow[t]{2}{*}{ Wyszczególnienie } & \multicolumn{4}{|c|}{$\begin{array}{l}\text { Udział w gospodarstwach } \\
\text { o skali produkcji tuczników }\end{array}$} & \multicolumn{3}{|c|}{$\begin{array}{c}\text { Udział tuczników } \\
\text { transportowanych na odległość }\end{array}$} \\
\hline & $1-20$ & $21-50$ & $51-100$ & $\begin{array}{c}\text { powyżej } \\
100\end{array}$ & $\begin{array}{l}\text { poniżej } \\
20 \mathrm{~km}\end{array}$ & $20-50 \mathrm{~km}$ & $\begin{array}{c}\text { powyżej } \\
50 \mathrm{~km}\end{array}$ \\
\hline \multicolumn{8}{|c|}{ Załadunek tuczników z wykorzystaniem: } \\
\hline windy & - & - & 16,8 & 85,7 & 2,3 & 21,4 & 40,0 \\
\hline pochylni & 100,0 & 100,0 & 83,2 & 14,3 & 97,8 & 78,6 & 60,0 \\
\hline \multicolumn{8}{|c|}{ Przewóz tuczników realizowany: } \\
\hline agregatem rolniczym & 100,0 & 6,3 & 29,2 & - & 62,9 & 7,2 & - \\
\hline $\begin{array}{l}\text { pojazdem } \\
\text { dostawczym } \\
\text { specjalistycznym }\end{array}$ & - & 93,8 & 70,8 & 28,6 & 16,9 & 35,7 & 30,0 \\
\hline $\begin{array}{l}\text { pojazdem } \\
\text { ciężarowym } \\
\text { specjalistycznym } \\
\text { wielopokładowym }\end{array}$ & - & - & - & 33,3 & - & 21,4 & 40,0 \\
\hline $\begin{array}{l}\text { pojazdem } \\
\text { ciężarowym } \\
\text { specjalistycznym } \\
\text { jednopokładowym }\end{array}$ & - & - & - & 38,1 & 20,2 & 35,7 & 30,0 \\
\hline \multicolumn{8}{|c|}{ Typ podłogi stosowany w pojeździe: } \\
\hline metalowa & 43,2 & 28,1 & 75,0 & 100,0 & 46,0 & 92,9 & 100,0 \\
\hline drewniana & 56,8 & 71,9 & 25,0 & - & 54,0 & 7,1 & - \\
\hline \multicolumn{8}{|c|}{ W pojeździe wykorzystywany system: } \\
\hline bezściołowy & 8,1 & 3,1 & 12,5 & - & 93,0 & 100,0 & 100,0 \\
\hline ściołowy & 91,9 & 96,9 & 87,5 & 100,0 & 6,9 & - & \\
\hline \multicolumn{8}{|c|}{ Rodzaj stosowanej ściółki: } \\
\hline słoma & 83,8 & 62,5 & 54,0 & 61,9 & 17,3 & - & 20,0 \\
\hline trociny & 5,4 & 6,3 & 29,3 & 28,6 & 9,9 & 28,6 & 20,0 \\
\hline siano & 10,8 & 31,2 & 16,7 & 9,5 & 72,8 & 71,4 & 60,0 \\
\hline \multicolumn{8}{|c|}{ Obsada tuczników [m²/tucznik]: } \\
\hline$<0,45$ & 1,8 & - & 5,3 & 38,8 & 6,2 & 57,6 & 26,1 \\
\hline $0,45-55$ & 2,3 & - & 41,0 & 26,1 & 15,9 & 23,6 & 22,3 \\
\hline$>55$ & 96,0 & 100,0 & 53,7 & 35,2 & 77,9 & 18,7 & 51,5 \\
\hline \multicolumn{8}{|c|}{ Obrażenia i zmęczenie tuczników: } \\
\hline obrażenia & 26,7 & 50,1 & 40,2 & 58,0 & 30,2 & 39,6 & 61,5 \\
\hline zmęczenie & 17,3 & 24,6 & 20,1 & 31,4 & 11,4 & 22,8 & 37,2 \\
\hline
\end{tabular}

Źródło: wyniki badań własnych. 
transportowanych na najkrótszym dystansie do $20 \mathrm{~km}$. W badaniach wykazano tendencję do zmniejszania udziału tej metody załadunku wraz z rosnącą odległością transportu świń. W przypadku transportów powyżej $50 \mathrm{~km}$ udział pochylni obniżył się do $60 \%$. Zwierzęta transportowane nieodpowiednimi środkami transportu narażone są na wiele zagrożeń, z których najczęściej wskazuje się obrażenia zewnętrzne, kontuzje, wysokie ubytki masy ciała, pogorszenie cech jakościowych mięsa wynikające ze wzrostu udziału tusz, w których stwierdza się tzw. miopatie mięśniowe.

Gama środków transportowych, które w Polsce są wykorzystywane do przewozu zwierząt, jest bardzo szeroka i zróżnicowana pod względem technicznym [Kokoszka 2003, Matysek i in. 2013]. Zgodnie z wymaganiami prawnymi pojazd do przewozu zwierząt powinien być tak zaprojektowany, aby nie powodował obrażeń i okaleczeń zwierząt i gwarantował zapewnienie optymalnych warunków mikroklimatu. Przestrzeń ładunkowa w pojazdach do transportu zwierząt powinna być wykonana z materiałów odpornych na korozję i łatwych do dezynfekcji [Rozporządzenie Rady (WE) 2005]. Powyższych wymogów nie muszą spełniać pojazdy, którymi wykonywany jest transport niemający charakteru handlowego, dotyczy przewozu pojedynczych zwierząt, jego odległość nie przekracza odległości $50 \mathrm{~km}$, a zwierzęta są transportowane przez hodowców [Nieoczym 2014]. Według S. Kokoszki, w transporcie zwierząt obok pojazdów specjalistycznych nadal na szeroką skalę wykorzystuje się adaptowane środki transportowe, w tym samochody ciężarowe z przyczepami oraz agregaty rolnicze. Za pomocą agregatów rolniczych przewoziło się w 2008 roku prawie $50 \%$ zwierząt transportowanych do uboju bezpośrednio przez producentów [Kokoszka 2009].

W tabeli 1. zestawiono strukturę typów pojazdów wykorzystywanych do przewozu tuczników w badanych operacjach transportowych. Z danych tych wynika, że zwierzęta były przewożone zarówno pojazdami specjalistycznymi, jak i pojazdami adaptowanymi do tych zadań. Udział poszczególnych typów pojazdów był wyraźnie zróżnicowany w zależności od skali produkcji i od odległości transportu zwierząt. Z gospodarstw o rocznej produkcji do 20 tuczników zwierzęta do uboju dostarczano wyłącznie agregatami rolniczymi. Z informacji zgromadzonych w czasie badań wynika, że w ten sposób były przewożone zwierzęta z gospodarstw dostarczających do uboju jednorazowo kilka sztuk zwierząt, a pojazdy te stanowiły w większości własność producentów. Zdaniem S. Kokoszki, wykorzystywanie agregatów rolniczych do przewozu zwierząt jest nieuzasadnione ze względów ekonomicznych. Środki transportowe tego typu generują wysokie koszty eksploatacji. Są to również pojazdy wolnobieżne, co dodatkowo wydłuża czas transportu zwierząt [Kokoszka 2009]. W badaniach wykazano, że w miarę wzrostu skali produkcji zwierząt udział agregatów rolniczych obniżał się, a wzrastało znaczenie środków specjalistycznych, w tym samochodów dostawczych. Samochody dostawcze były najczęściej używanym środkiem transportu w gospodarstwach o rocznej skali produkcji od 20 do 100 tuczników. Do zadań transportowych z gospodarstw o największej skali produkcji używano przede wszystkim specjalistycznych pojazdów ciężarowych, w tym wielopokładowych.

Wyniki badań wskazują na wyraźne zróżnicowanie typów pojazdów stosowanych do przewozu świń w zależności od odległości transportu. Tuczniki transportowane na odległość poniżej $20 \mathrm{~km}$ były przewożone głównie agregatami rolniczymi. Wraz ze wzrostem odległości udział agregatów ulegał wyraźnemu zmniejszeniu na korzyść samochodów dostawczych, których udział wynosił ponad 35\% w transporcie na odległość od 21 do 50 $\mathrm{km}$ i 30\% w transporcie powyżej $50 \mathrm{~km}$. Największy udział w przewozach powyżej 50 $\mathrm{km}$ miały specjalistyczne pojazdy wielopokładowe. Zastosowanie tego typu pojazdów w przewozach zwierząt na długich dystansach było uzasadnione ekonomiczne. Pojazdy tego 
typu pozwalają jednorazowo na przewóz dużej liczby zwierząt, co znacząco ogranicza jednostkowe koszty transportu [Matysek i in. 2013]. Użycie pojazdów specjalistycznych, zarówno jedno- jak i wielopokładowych, do przewozów na dystansach powyżej $50 \mathrm{~km}$ wynika również z konieczności przestrzegania przez przewoźników obowiązujących regulacji prawnych [Nieoczym 2014].

W badaniach określono materiały, z których wykonane były podłogi w środkach do przewozu zwierząt. Stwierdzono, że podłogi były metalowe bądź drewniane. W przypadku gospodarstw o mniejszej skali produkcji zwierzęta częściej były przewożone na podłogach drewnianych (tab. 1.). Ten rodzaj podłogi odnotowano w 56,8\% pojazdów przewożących świnie z gospodarstw produkujących rocznie do 20 tuczników i aż 71,9\% pojazdów w grupie gospodarstw dostarczających od 21 do 50 świń. W pojazdach, którymi transportowano zwierzęta z większych gospodarstw, zdecydowanie częściej podłogi były metalowe. Niewątpliwie miało to związek z rodzajami środków transportu, którymi były przewożone świnie z tych obiektów. Nowoczesne środki transportu mają zazwyczaj podłogi wykonane z materiałów odpornych na korozję i jest to najczęściej stal kwasoodporna lub inne materiały kompozytowe [Fabirkiewicz 2003]. Ten rodzaj podłóg pozwalana na utrzymanie wysokich standardów sanitarnych w pojazdach oraz łatwą i szybką ich dezynfekcję [Matysek $\mathrm{i}$ in. 2013]. Podłogi metalowe zdecydowanie dominowały również w pojazdach, którymi transportowano tuczniki na większe odległości. Metalową podłogę posiadały wszystkie pojazdy wykorzystywane do transportu powyżej $50 \mathrm{~km}$ i 92,9\% pojazdów przewożących świnie na odległość $21-50 \mathrm{~km}$.

Z licznych badań [EFSA 2011, Schwartzkopf-Genswein i in. 2012, Tereszkiewicz i in. 2017] wynika, że dostępność ściółki w pojazdach transportujących zwierzęta wpływa korzystnie na dobrostan. Zasadniczym celem stosowania ściółki jest podniesienie warunków sanitarnych oraz komfortu termicznego. Ze względów sanitarnych dobra ściółka powinna charakteryzować się zdolnością wiązania wilgoci i absorbcji odorów. Ściółka powinna mieć również wysoką termoizolacyjność. Stosowanie ściółki zaleca się przede wszystkim $\mathrm{w}$ transportach realizowanych w sezonach jesienno-zimowych przy temperaturze poniżej $10^{\circ} \mathrm{C}$, zwłaszcza w pojazdach, w których podłogi wykonane są z metalu. Równocześnie stosowanie ściółki stwarza pewne problemy organizacyjne, które wynikają z konieczności jej magazynowania oraz rozścielenia w pojazdach, a w dalszej kolejności usunięcia i utylizacji. Z badań amerykańskich wynika, że koszty związane z tymi zabiegami są szacowane są na poziomie 30-70 dolarów na jeden transport [Schwartzkopf-Genswein i in. 2012]. Wyniki przeprowadzonych badań wskazują, że mimo licznych trudności i wysokich kosztów przewoźnicy zwierząt w zasadniczej większości stosowali w środkach transportu ściółkę. Na ściółce do uboju było dowożonych ponad $90 \%$ tuczników, w tym wszystkie z gospodarstw o skali produkcji powyżej 100 zwierząt rocznie oraz wszystkie zwierzęta transportowane na dystansach 21-50 km i powyżej $50 \mathrm{~km}$ (tab. 1.). Ponadto w badaniach stwierdzono, że jako ściółkę stosowano różne materiały, w tym siano, trociny i słomę. W zorganizowanych, nowoczesnych przewozach zwierząt na długich dystansach jako ściółkę najczęściej wykorzystuje się trociny oraz słomę. Najpopularniejszym materiałem ściołowym, który wykorzystywano niezależenie od skali produkcji i odległości transportu, była słoma. Przy czym największy udział słomy odnotowano w transportach wykonywanych od dostawców produkujących rocznie do 20 tuczników oraz w transportach na odległość do $20 \mathrm{~km}$ (tab. 1.).

Do standardowych wymogów w transporcie zwierząt, wpisanych w idee wysokiego dobrostanu, należy zapewnienie odpowiedniej powierzchni podłogi w przestrzeni ładun- 
kowej [Rozporządzenie Rady (WE) 2005]. Norma obsady trzody chlewnej w pojeździe wynosi $235 \mathrm{~kg} / \mathrm{m}^{2}$. Dla obliczania powierzchni niezbędnej dla poszczególnych zwierząt z uwzględnieniem ich masy ciała rekomendowany jest wzór [EFSA 2011]:

\section{$0,027 \times$ masa ciała tucznika ${ }^{0,66}$}

Obsada zwierząt jest ważnym wskaźnikiem oceny organizacji operacji transportowych, wpływa również na poziom dobrostanu. $Z$ wielu publikacji wynika, że obowiązujące normy przewozu świń nadal nie są przestrzegane. Tuczniki są przewożone w zbyt dużym lub zbyt małym zagęszczeniu [EFSA 2011, Schwartzkopf-Genswein i in. 2012]. Zjawisko to potwierdziły również przeprowadzone badania.

Szczególne zaniepokojenie budzi wysoki udział, bo wynoszący 38,78\%, przewozów tuczników w zbyt dużym zagęszczeniu (poniżej $0,45 \mathrm{~m}^{2}$ na jedno zwierzę), które obserwowano w przypadku tuczników pochodzących z gospodarstw o największej rocznej skali produkcji (tab. 1.). Jak można przypuszczać, nadmierna obsada zwierząt była istotnym czynnikiem wpływającym na wysoki odsetek tuczników z tych gospodarstw, u których obserwowano obrażenia ciała. Związek między obsadą tuczników w środkach transportu a uszkodzeniami ciała wykazali M. Ritter z zespołem. Z badań tych wynika, że zarówno zwiększenie, jak i zmniejszenie obsady w stosunku do obowiązujących limitów powoduje wzrost udziału tuczników z obrażeniami ciała [Ritter i in. 2006]. Również według Andrzeja Pisuli i Tomasza Florowskiego, transport świń zarówno w zbyt małej, jak i zbyt dużej obsadzie na jednostkę powierzchni nie jest wskazany. Zdaniem tych badaczy zbyt małe zagęszczenie może być przyczyną wzrostu wskaźnika obrażeń, co wynika z trudności w utrzymaniu przez zwierzęta równowagi. Z kolei zbyt duża obsada ogranicza ruch, utrudnia lub uniemożliwia przyjęcie pozycji leżącej i powoduje nasilenie walk o charakterze terytorialnym, co prowadzi do wzrostu udziału zwierząt wykazujących objawy zmęczenia potransportowego [Pisula, Florowski 2009].

Przeprowadzone badania wykazały bardzo wysoki udział operacji transportowych, w których tuczniki były przewożone w zbyt małym zagęszczeniu. Jak wykazano, w niskiej obsadzie były transportowane praktycznie wszystkie tuczniki dostarczane do uboju z odległości do $20 \mathrm{~km}$. Bardzo wysoki udział tuczników, które transportowano w obsadzie poniżej zalecanych norm, dotyczył głównie transportów realizowanych z gospodarstw znajdujących się w najbliższym otoczeniu zakładów ubojowych. Dostawy te były realizowane głównie z wykorzystaniem agregatów rolniczych (tab. 1.), którymi przewożono pojedyncze zwierzęta lub maksymalnie kilka sztuk. Transporty te były realizowane przez samych producentów, którzy nie korzystali z zewnętrznych firm świadczących usługi w zakresie transportu zwierząt.

Transport świń do uboju przyczynia się do powstawania uszkodzeń mechanicznych skóry, tkanek podskórnych oraz kości [Ritter i in. 2006, Tereszkiewicz, Dunin-Mugler 2001, Tereszkiwicz i in. 2003]. Zmiany te przyjmują najczęściej postać ran, złamań, otarć. Reakcją tuczników na obrażenia ciała jest niepokój, wzrost agresywności i stresopodatności. Obrażenia zwierząt, ich skala, charakter i rozmieszczenie są bardzo dobrym wskaźnikiem oceny poziomu dobrostanu zwierząt w transporcie [Kołacz, Bodak 1999, Nanni-Costa i in. 1999, Ritter i in 2009]. Z dotychczas przeprowadzonych licznych badań własnych [Tereszkiewicz, Dunin-Mugler 2001, Tereszkiewicz i in. 2003, Tereszkiewicz i in. 2004], dotyczących oceny przyczyn i skutków obrażeń tuczników w transporcie wynika, że obrażenia występują bardzo powszechnie, a ich głównymi przyczynami są odległość i czas transportu oraz wzajemne walki zwierząt pochodzących od różnych producentów i połączonych we wspólne grupy na czas transportu. M. Ritter z zespołem podkreślali negatywny 
wpływ łączenia tuczników pochodzących z różnych stad na występowanie obrażeń ciała [Ritter i in. 2006]. Wykazali oni, że w grupach jednorodnych skala obrażeń była istotnie niższa $\mathrm{w}$ porównaniu $\mathrm{z}$ transportami, $\mathrm{w}$ których wspólnie przewożono świnie $\mathrm{z}$ różnych farm. Znaczący udział w generowaniu obrażeń ma również płeć tuczników, sezon transportu, metoda załadunku. Na uszkodzenia wpływa także stan techniczny i wyposażenie pojazdów. Powstałe podczas transportu obrażenia ciała tuczników mają istotne znaczenie komercyjne. Obniżają klasę handlową i przydatność przetwórczą tusz. Z technologicznego punktu widzenia obecność na tuszach zmian, które są wynikiem urazów doznanych w czasie transportu znacząco obniża ich wartość i atrakcyjność handlową. Tusze ze stwierdzonymi obrażeniami, są również mniej wartościowe jako surowiec do produkcji elementów rozbiorowych i muszą być przeznaczone do wykrawania. Wyniki najnowszych badań wskazują, że udział tuczników z obrażeniami ciała wynosił ponad 57\% [Tereszkiewicz i in. 2017]. Najczęściej obrażenia stwierdza się w przedniej partii ciała oraz na zadzie. Uważa się, że zmiany w obrębie przedniej części ciała są związane z przepędami zwierząt, zwłaszcza ich załadunkiem i wyładunkiem oraz prowadzonymi walkami. Przyczyną uszkodzeń zadu jest głównie obskakiwanie się zwierząt.

Z przeprowadzonych badań wynika, że obrażenia ciała stwierdzono u znacznej liczby ocenianych zwierząt (tab. 1.). Szczególnie wysoki, bo przekraczający 50\% odsetek świń z obrażeniami odnotowano w przypadku zwierząt pochodzących z gospodarstw o rocznej skali produkcji wynoszącej od 21 do 50 oraz powyżej 100 tuczników. Należy przypuszczać, że tak wysoki udział zwierząt z obrażeniami w grupie gospodarstw największych miał związek z częstymi przypadkami przekroczenia dopuszczalnych norm obsady. Warto również zwrócić uwagę, że znaczna część tuczników pochodzących z gospodarstw o największej rocznej skali produkcji wykazywała objawy zmęczenia w chwili ich dostarczenia do uboju.

W badaniach wykazano również znaczący wzrost udziału zwierząt z obrażeniami, jak też wykazujących objawy zmęczenia wraz z wzrostem odległości transportu (tab. 1.). W przypadku transportów na odległość $100 \mathrm{~km}$ odsetek zwierząt z obrażeniami i objawami zmęczenia wynosił odpowiednio $61,5 \%$ oraz $37,2 \%$. Negatywny wpływ długości transportu oraz czasu jego trwania na kondycję zwierząt potwierdzono w licznych badaniach [EFSA 2011, Schwartzkopf-Genswein i in. 2012]. Jako główne przyczyny tych zależności wskazuje się negatywne czynniki związanie z długotrwałym ruchem pojazdów, takie jak: wibracje, hamowanie, zmiany prędkości, kierunku ruchu, działanie siły odśrodkowej i bezwładności. Wyniki wcześniejszych badań wskazują, że długi okres transportu może być przyczyną stresu transportowego prowadzącego do zmęczenia czy nawet wyczerpania zwierząt, co prowadzi do obniżenia jakości technologicznej surowca rzeźnego na skutek wzrostu udziału mięsa DFD (ang. dark, firm, dry - mięso ciemne, twarde, suche).

W opracowaniu oszacowano straty ekonomiczne wynikające ze zmęczenia zwierząt i obrażeń ciała doznanych w czasie ich transportu. Są to najczęściej opisywane w literaturze [Ritter i in. 2009, Pisula, Florowski 2008] przyczyny obniżenia wartości handlowej produkowanego surowca rzeźnego. Stwierdzono, że zarówno straty wynikające z obrażeń ciała, jak i ze zmęczenia tuczników wzrastały wraz z odległością transportu oraz skalą produkcji tuczników w gospodarstwach rolnych (tab. 2.). Łączna wartość oszacowanych strat transportowych w przeprowadzonym badaniu wynosiła 4242,43 zł. Analizując poziom strat w przeliczeniu na jednego transportowanego tucznika ustalono, że ich wartość była najwyższa wśród zwierząt pochodzących z gospodarstw rolniczych o skali produkcji powyżej 100 transportowanych tuczników rocznie (1,21 zł) oraz wśród zwierząt transportowanych na odległość powyżej $100 \mathrm{~km}(1,33 \mathrm{zł})$. 
Tabela 2. Straty ekonomiczne w transporcie tuczników

\begin{tabular}{|c|c|c|c|c|c|c|}
\hline \multirow{2}{*}{$\begin{array}{l}\text { Wyszcze- } \\
\text { gólnienie }\end{array}$} & \multicolumn{2}{|c|}{ Masa tuczników } & \multicolumn{2}{|c|}{ Strata wynikająca } & \multicolumn{2}{|c|}{ Strata } \\
\hline & $\begin{array}{c}\text { z objawami } \\
\text { zmęczenia } \\
{[\mathrm{kg}]}\end{array}$ & $\begin{array}{c}\text { z obrażeniami } \\
\text { ciała } \\
{[\mathrm{kg}]}\end{array}$ & $\begin{array}{c}\text { ze zmęczenia } \\
\text { tuczników } \\
{[\mathrm{zl}]}\end{array}$ & $\begin{array}{c}\text { z obrażeń } \\
\text { tuczników } \\
\text { [zł] }\end{array}$ & $\begin{array}{c}\text { razem } \\
{[\mathrm{zl}]}\end{array}$ & $\begin{array}{c}\text { na jednego } \\
\text { tucznika } \\
{[\mathrm{zt}]}\end{array}$ \\
\hline \multicolumn{7}{|c|}{ Skala produkcji [szt.] } \\
\hline $1-20$ & 14250 & 19875 & 265,22 & 126,11 & 391,33 & 0,67 \\
\hline $21-50$ & 15875 & 32125 & 295,47 & 203,83 & 499,30 & 0,99 \\
\hline $51-100$ & 35250 & 68375 & 656,07 & 433,84 & 1089,91 & 0,81 \\
\hline Powyżej 100 & 75250 & 135750 & 1400,55 & 861,33 & 2261,89 & 1,21 \\
\hline \multicolumn{7}{|c|}{ Odległość transportowa } \\
\hline Poniżej $20 \mathrm{~km}$ & 13375 & 36625 & 248,94 & 232,39 & 481,32 & 0,48 \\
\hline $20-50 \mathrm{~km}$ & 32375 & 58000 & 602,56 & 368,01 & 970,57 & 0,81 \\
\hline Powyżej 100 km & 94875 & 161500 & 1765,81 & 1024,72 & 2790,53 & 1,33 \\
\hline Razem & 140625 & 256125 & 2617,31 & 1625,11 & 4242,43 & 0,99 \\
\hline
\end{tabular}

Źródło: obliczenia na podstawie badań własnych.

\section{PODSUMOWANIE}

Z przeprowadzonych badań wynika, że zwierzęta dostarczane do zakładów ubojowych na Podkarpaciu były przewożone zarówno pojazdami specjalistycznymi, jak i adaptowanymi środkami transportowymi, głównie agregatami rolniczymi. Udział poszczególnych typów pojazdów był zróżnicowany w zależności od skali produkcji i od odległości transportu zwierząt. Pojazdy specjalistyczne częściej wykorzystywano w transporcie na większe odległości i z gospodarstw o większej rocznej skali produkcji tuczników. Zwierzęta z małych gospodarstw do uboju dostarczano wyłącznie agregatami rolniczymi. Stwierdzono, że trzodę przewożono w pojazdach wyposażonych w podłogi metalowe z systemem ściołowym. Przeprowadzone badania wykazały liczne przypadki przekroczenia dopuszczalnych norm obsady tuczników w czasie transportu, głównie w transportach realizowanych od największych producentów. W badaniach wykazano, że wraz ze wzrostem przebytej odległości transportu znacząco zwiększał się udział zwierząt zmęczonych i z obrażeniami ciała. Łączna wartość oszacowanych strat transportowych w przeprowadzonym badaniu wynosiła 4242,43 zł. Najwyższe straty ekonomiczne wynikające z obniżenia dobrostanu tuczników w przeliczeniu na jedno transportowane zwierzę odnotowano w przewozach na najdłuższym dystansie oraz z gospodarstw o największej skali produkcji. Konstatując, należy stwierdzić, że doskonalenie warunków przewozu i dobrostanu tuczników w transporcie może przyczynić się do poprawy jakości handlowej surowca mięsnego oraz ograniczenia finansowych kosztów transportu. Straty powstałe na etapie transportu mogą determinować efektywność dalszych etapów przetwórstwa oraz ograniczać kierunki zagospodarowania technologicznego surowca rzeźnego. 


\section{LITERATURA}

Cierach Marek, Natalia Idaszewska, 2014: Transport samochodowy zwierząt rzeźnych, „Inżynieria Przetwórstwa Spożywczego", vol. 1(9), s. 21-25.

EFSA, 2011: Scientific Opinion Concerning the Welfare of Animals during Transport, EFSA Panel on Animal Health and Welfare (AHAW), "EFSA Journal", vol. 9(1).

Fabirkiewicz Antoni, 2003: Transport zwierząt, wymagania prawne i rozwiąania techniczne, „Wieś Jutra", vol. 9, s. 24-27.

Kephart Rebecca, Anna Johnson, Kenneth Stalder, Ted Huiatt, Avi Sapkota, 2014: Costs of Bedding, Trailer Washout, and Transport Losses in Market Weight Pigs, „Animal Industry Report 2014”.

Kołacz Roman, 2010: Minimalne wymogi w zakresie transportu świń, „Trzoda Chlewna”, vol. 10, s. 75-78.

Kołacz Roman, Ewa Bodak, 1999: Dobrostan zwierząt i kryteria jego oceny, „Medycyna Weterynaryjna", vol. 55, s. 147-154.

Kokoszka Stanisław, 2003: Organizacja i funkcjonowanie ustug transportowych w rolnictwie, „Wieś Jutra", vol. 9, s. 32-35.

Kokoszka Stanisław, 2009: Postęp technologiczny a wydajność i koszty w transporcie zwierząt, „Problemy Inżynierii Rolniczej”, vol. 4, s. 37-44.

Kusz Dariusz, 2005: Specjalizacja a efektywność gospodarstw ukierunkowanych na produkcjężywca wieprzowego, „Roczniki Naukowe Stowarzyszenia Ekonomistów Rolnictwa i Agrobiznesu”, t. VII, vol. 1, s. 150-155.

Malak-Rawlikowska Agata, Monika Gębska, 2010: Postrzeganie dobrostanu zwierzat przez uczestników łańcucha żywnościowego w wybranych krajach Unii Europejskiej $i$ w Polsce, „Roczniki Nauk Rolniczych", t. 97, vol. 4, s. 135-148.

Matysek Konrad, Jerzy Chojnacki, Andrzej Grieger, Edmund Dulcet, 2013: Pojazdy specjalistyczne do transportu zwierzat, „Autobusy” vol. 10, s. 189-192.

Nanni Costa Leonardo, Pietro Lo Fiego Domenico, Stefania Dall'Olio, Roberta Davoli, Vincenzo Carlo Russ, 1999: Influence of loading method and stocking density during transport on meat and dry-cured ham quality in pigs with different halothane genotypes, „Meat Science”, vol. 51, s. 391-399.

Nieoczym Aleksander, 2014: Transport zwierzat - wymagania prawne i kontrola, „Logistyka”, vol. 4, s. 923-929.

Pisula Andrzej, Tomasz Florowski, 2008: Zmiany ilościowe i jakościowe mięsa w trakcie jego pozyskiwania i przetwarzania, „Gospodarka Mięsna”, vol. 2, s. 8-14.

Ritter Matthew, Martin Ellis, Janine Brinkmann, Jacob DeDecker, Kerry Keffaber, Edward Kocher, Benjamin Peterson, Johannes Schlipf, Bradley Wolter, 2006: Effect of floor space during transport of market-weight pigs on the incidence of transport losses at the packing plant and relationships between transport conditions and losses, „Journal of Animal Science”, vol. 84, s. 2856- 2864.

Ritter Matthew i in., 2009: Transport Losses in Market Weight Pigs: I. A Review of Definitions, Incidence, and Economic Impact, „Animal Scientist”, vol. 25, s. 1080-7446.

Rozporzadzenie Rady (WE) nr 1/2005 z dnia 22 grudnia 2004 r. w sprawie ochrony zwierzat podczas transportu i zwiazanych z tym działań oraz zmieniajace dyrektywy 64/432/EWG i 93/119/WE oraz rozporzadzenie (WE) $n r$ 1255/97.

Tereszkiewicz Krzysztof, Cezary Dunin-Mugler, 2001: Ubytki masy ciała, wydajność rzeźna i uszkodzenia skóry tuczników transportowanych na odległość 200 kilometrów, „Zeszyty Naukowe AR w Krakowie", vol. 36, s. 39-50.

Tereszkiewicz Krzysztof, Piotr Molenda, Karolina Choroszy, Łukasz Kulig, 2017: Warunki transportu i kondycja tuczników z dostaw bezpośrednich do zaktadów ubojowych na Podkarpaciu, „Autobusy”, vol. 6, s. 1574-1578.

Tereszkiewicz Krzysztof, Piotr Molenda, Irena Nowotyńska, Kazimierz Pokrywka, 2012: Ocena dobrostanu tuczników w czasie transportu, „Logistyka” vol. 3, s. 2277-2284.

Tereszkiewicz Krzysztof, Piotr Molenda, Kazimierz Pokrywka, 2011: Aktualne problemy w transporcie tuczników, „Logistyka”, vol. 3, s. 2787-2798. 
Tereszkiewicz Krzysztof, Maria Ruda, Kazimierz Pokrywka, 2003. Wpływ odległości transportu tuczników na uszkodzenia skóry oraz możliwości zagospodarowania ich tusz, „Przegląd Hodowlany", vol. 11, s. 8-10.

Tereszkiewicz Krzysztof, Maria Ruda, Kazimierz Pokrywka, 2004: Wpływ odległości transportu na wartość poubojowa tuczników, „Annales UMCS”, vol. 22, s. 145-153.

Schwartzkopf -Genswein Karen, Luigi Faucitano, Samira Dadgar, Phyllis Shand, Luciano González, Trever Crowe, 2012: Road transport of cattle, swine and poultry in North America and its impact on animal welfare, carcass and meat quality: A review, „Meat Science”, vol. 92, s. 227-243.

Utnik-Banaś Katarzyna, 2015: Struktura gospodarstw specjalizujacych się w produkcji trzody chlewnej w Polsce, „Problemy Drobnych Gospodarstw Rolnych”, vol. 2, s. 69-80.

Zagrożenia dla sektora trzody chlewnej ze strony ASF. Propozycja Projektu Zwalczania Afrykańskiego Pomoru Świń w Polsce, 2015: POLSUS Warszawa.

Ziętara Wojciech (red.), 2014. Polskie gospodarstwa trzodowe i drobiarskie na tle gospodarstw wybranych krajów Unii Europejskiej, Warszawa, IERiGŻ-PIB.

https://bdl.stat.gov.pl/BDL/start, data dostępu 14.12.2017.

\title{
Krzysztof Tereszkiewicz, Piotr Molenda, Dariusz Kusz \\ EVALUATION OF TRANSPORT CONDITIONS AND THE WELFARE OF FATTENERS \\ IN LOCAL TRANSPORT
}

\begin{abstract}
Summary
The aim of the study was to evaluate the conditions of transport and the welfare of fatteners as well as to assess transport losses depending on the distance of transport and the annual production scale of fatteners. The material comprised data describing 120 transport operations during which 4300 fatteners were transported for slaughter. The study shows that animals were transported both by means of specialized vehicles as well as by adapted means of transport, mainly agricultural aggregates. Specialized vehicles were more often used in long-distance transport and from farms with a larger annual production scale. The research showed numerous cases of exceeding admissible norms of the number of fatteners during transport, mainly in the transport carried out by the largest producers. The study proved that the percentage of tired and injured animals rose as the distance of transport increased. The greatest economical losses resulting from the decrease in the welfare of the fatteners per one transported animal was observed in transport at the longest distance and from farms with the largest production scale.
\end{abstract}

Adres do korespondencji:

Dr hab. inż. Krzysztof Tereszkiewicz prof. PRz, dr inż. Dariusz Kusz Politechnika Rzeszowska, Wydział Zarządzania Zakład Informatyki w Zarządzaniu al. Powstańców Warszawy 8, 35-959 Rzeszów e-mail: kteresz@prz.edu.pl; dkusz@prz.edu.pl 